\title{
Concluding narratives of a career with dementia: accounts of Iris Murdoch at her death
}

\author{
GILLIAN MaCOLGAN*, JAMES VALENTINE** and \\ MURNA DOWNS*
}

\begin{abstract}
Obituaries and other accounts of well-known people at their death offer a narrative defining identity through the life story. It is particularly poignant when the story is told of an author, and draws upon not only life course metaphors but also features of the author's fiction. In this paper we look at a case where the dementia of a famous author figures in the tributes at her death. The predominant narrative of dementia has until recently been that of a tragic loss of self. This has reinforced an image of social death. Biomedical determinism has similarly focused on the disease, rather than seeing the person and allowing their voice to be heard. While Iris Murdoch may not have wanted tributes to tell her story, they have allowed us to examine conventional narratives of a person with dementia. We chart the 'career' of a person with dementia, and their perceived transformation of identity, defined in terms of being demented rather than with dementia. Bad and good are attributed to aspects of Iris Murdoch's life through a repertoire of available stereotypes. These appear to involve the retrospective application of characteristics of dementia, along with those of goodness and purity. Common gender representations relating to Iris Murdoch's married life and the caring situation are interwoven in the accounts. We are told a story that reflects and reproduces conventional narratives of the life course and of dementia, characterising the deceased in terms of a moral career.
\end{abstract}

$\boldsymbol{K} \boldsymbol{E} \boldsymbol{Y}$ WORDS - narrative, accounts, biography, author, obituaries, life course, death, dementia, career, care.

\section{Introduction: life stories}

Narrative is increasingly recognised as the way in which we make sense of our lives. Both Ricoeur ( I 992) and Harré ( 1998) emphasise the role of narrative in the construction of the identities of self and others. This is hardly new, as earlier symbolic interactionist works emphasised the

* Centre for Social Research on Dementia, Department of Applied Social Science, University of Stirling

** Sociology and Social Policy, Department of Applied Social Science, University of Stirling 
way in which, through accounts of our past, present and future, we reflexively construct ourselves. ${ }^{1}$ Strauss (I997), in particular, noted how our accounts, telling how we have come to be what we are today, construct a version of the past that tells a story of consistency or meaningful disjuncture. Transformations of identity have to be explained, and provide the opportunity, or even necessity, to reform our accounts.

Death itself can be seen as such a transformation, a grand one, and one that might be seen as offering a concluding chance for presenting an account of a life. The notion of account is pertinent, as it implies not just recounting, but holding to account, adding up the significance and worth of a human life. In a culture still influenced, especially in death, by the Christian tradition, there is a strong belief that the final tally cannot be known until the life is ended, when the conclusion is known.

Obituaries are the immediate concluding narratives of a person's life. They mark the conclusion, a day of reckoning with those who have the power to judge a life, and provide the conclusion, the account that sums up a life. As concluding narratives, obituaries reflect the preoccupation with the sense of an ending (Kermode i973), a narrative order that suggests a causal sequence through life. Modernist fiction may have come to doubt such narratives, yet postmodernism insists that it is modernism that creates the grand narratives (Lyotard i 984): each cultural phase characterises itself as the age of doubt and disbelief.

Postmodernism tells a supposedly new story, in which we are all the authors of our selves, freely (re-)presenting narratives of identity, in a situation where power is dispersed. The enduring tradition of obituaries suggests otherwise. Obituaries continue to provide the authoritative conclusion to a life: telling a life story, and doing so with the legitimacy of expertise. The expert provides the concluding words - though not, of course, the final ones, as reputations continue to rise and fall through later recounting. At the conclusion of a life, expertise is called upon to provide the summing up: mere personal knowledge of the deceased is not enough. 'Conventionally, obituarists explain neither how they (rather than someone else) come to be writing the obituary, nor the nature of their relationship to the deceased' (Bytheway and Johnson I 996: 230). While skills in particular areas of journalism give authority to news stories of the concluded life, obituaries call for a specialist connection to the field in which the deceased has made their name. Endorsing the notion that a personal relation is not enough, objectivity may be further suggested through the common convention of anonymity: unattributed opinions take on authority as the detached view of the newspaper as an impersonal institution. With the double 
legitimacy of expertise and objectivity, the self is characterised and accounted. Here, with all the power of experts to impose the identity of the other (Valentine I998), the living define the dead, those who have 'passed over' and are not in a position to respond. Obituaries are concluding life stories told by living experts.

In telling the story of a life, obituaries typically fail to show the doubts about narrative that are trumpeted by modernist fiction, and even by postmodernists who dissect modernism at its post-mortem and provide an obituary that may prove to be premature. Obituaries continue to be governed by the conventions of biography (albeit a potted one), in which typical metaphors of life are paraded at its conclusion: struggles which are now resolved, a journey which has ended, a life that has run its course. Bytheway and Johnson note that obituaries account 'whole - completed - life courses' ( I 996: 233), and that most 'provide a sequential account of the involvement of the deceased in the career or social world with which they were associated' ( 1996 : 224). The notion of a life course suggests a natural sequence, a unidirectional flow, or even a track with obstacles that are negotiated and overcome. Adopting this model of life lends to the obituary the taken-for-granted veracity of conventional narrative.

Obituaries of an author's life may be especially ironic: they tell the story of a storyteller in conventions that may be accepted or rejected by that author's narrative techniques. In the case of Iris Murdoch, a writer who (as the obituaries recount) was preoccupied with questions of good and evil, the moral account - the story of the triumph of good

- is particularly apposite. In another sense, however, any obituary of Iris Murdoch goes against her inclination to avoid having her own story told. She was famously reluctant to give interviews about herself, and to have her novels reduced to the level of a reflection of biography ${ }^{2}$.The greater truth that is claimed for biography over fiction is given the lie by its reliance on narrative: as Kermode notes about Iris Murdoch's Under the Net, 'one of the few truly philosophical novels in English; truth would be found only in a silent poem or a silent novel' (I973: 220)-or, one might add, a silent obituary. Yet a silent obituary, refraining from marking this life, would have missed the uncommon opportunity for public acknowledgement of the life of a person with dementia.

\section{Demented narratives}

People with dementia have been a silent presence. If we hear their voice it is predominantly through others. With a few notable exceptions such 
as Davis ( 1989), Friel-McGowin (1993) and Rose (1996), the stories of people's lives with dementia are told by others. These include family carers and academics. It has been argued by Holstein ( I998) that current images and representations of dementia help construct the 'loss of self' that is so widely associated with living with dementia. He stresses the importance of interpretation in understanding dementia. We are not aware of any examination of the public media with respect to its representation of people with dementia. Carers' reports of their family members' experience of dementia tend to focus on a tragic story of loss with titles such as Stolen Mind: the Slow Disappearance of Ray Doernberg (Doernberg I 989) and Remind Me Who I am Again (Grant I 998). Books for carers include titles such as The Loss of Self (Cohen and Eisdorfer I 986). John Bayley's ( I 998) memoir of Iris Murdoch is unusual in that it was written before her death and written not by her but by her husband. This highlights a prominent attitude about those who have dementia that they have already undergone a kind of 'social death' (Sweeting and Gilhooly r 997).

The academic lens through which people with dementia have been viewed and represented has largely been restricted to a biomedical deterministic one (Harding and Palfrey i 997). Through this lens people with dementia are reduced to a catalogue of cognitive deficits and behaviour disorders. Holstein (1998) stresses the role that such discourse about dementia can play by intensifying the negative effects of the experience of dementia by neglecting to examine the social, political and popular culture in which a life with dementia is lived out. In the last ten years this biomedical construct has been challenged by a range of academics, most notably Lyman (1989, I998), Kitwood (I 993), Bond (I 992) and Post (I 995). These critical gerontologists are more concerned with the subjective experience of dementia, the nature of personhood and the self, and the socio-cultural context of disease definition than with detailing its neuro-psychological deficits (Holstein I 998). For example, Post ( 1995, I 998) places dementia in its cultural and social context by cogently arguing that in our contemporary hyper-cognitive society, which values intellect, reasoning and selfcontrol, a person with dementia is denied their essential humanity. Lacking intellectual prowess, their affective, relational, spiritual and aesthetic dimensions of being are overshadowed.

\section{Concluding narratives of Iris Murdoch}

The accounts which were published on the day after Iris Murdoch's death provide us with a story of someone who has lived with dementia. 
TA в LE i. Newspaper references, Tuesday gth February 1999

\begin{tabular}{|c|c|c|c|c|}
\hline $\mathrm{No}^{1}$ & Author & Obituary or Report & Newspaper & $\begin{array}{l}\text { Place of } \\
\text { Publication }\end{array}$ \\
\hline I & Conrad, P. & Obituary & The Guardian & $\begin{array}{l}\text { London and } \\
\text { Manchester }\end{array}$ \\
\hline 2 & Bradbury, M. & $\begin{array}{l}\text { A distinctive, magical, } \\
\text { inventive imagination }\end{array}$ & The Guardian & $\begin{array}{l}\text { London and } \\
\text { Manchester }\end{array}$ \\
\hline 3 & $\begin{array}{l}\text { Ezard, J. } \\
\text { and Gentleman, A. }\end{array}$ & $\begin{array}{l}\text { A shining light even in } \\
\text { the darkest years }\end{array}$ & The Guardian & $\begin{array}{l}\text { London and } \\
\text { Manchester }\end{array}$ \\
\hline 4 & Anon. & $\begin{array}{l}\text { Tributes to the grande } \\
\text { dame of literature }\end{array}$ & The Herald & Glasgow \\
\hline 5 & Hensher, P. & Obituary & The Independent & London \\
\hline 6 & $\begin{array}{l}\text { Marks, K. and } \\
\text { Garner, C. }\end{array}$ & $\begin{array}{l}\text { The long voyage is finally } \\
\text { over as Dame Iris } \\
\text { Murdoch dies, aged } 79\end{array}$ & The Independent & London \\
\hline 7 & Taylor, D.J. & Obituary & The Scotsman & Edinburgh \\
\hline 8 & Thorpe, N. & $\begin{array}{l}\text { Queen of words who } \\
\text { shaped a generation }\end{array}$ & The Scotsman & Edinburgh \\
\hline 9 & Anon. & Obituary & The Daily Telegraph & London \\
\hline IO & Graves, D. & $\begin{array}{l}\text { Dame Iris, doyenne of } \\
\text { English Letters, dies at } 79\end{array}$ & The Daily Telegraph & London \\
\hline I I & Wilson, A.N. & $\begin{array}{l}\text { Novelist who shone a } \\
\text { kindly light on a godless } \\
\text { world }\end{array}$ & The Daily Telegraph & London \\
\hline I 2 & Anon. & Obituary & The Times & London \\
\hline I 3 & Wagner, E. & $\begin{array}{l}\text { Philosophical storyteller } \\
\text { with an open mind }\end{array}$ & The Times & London \\
\hline
\end{tabular}

1 These numbers are used subsequently in the text for reference.

Once again we hear a story told by others. In the case of Iris Murdoch, these others are viewed as qualified to write such accounts through known expertise (especially in the field of literature) or through the presumed expertise and objectivity conferred by anonymity. It is particularly poignant and informative to study such stories as they represent the life of a person known for her intellectual powers of storytelling who in latter years was diagnosed with probable Alzheimer's disease. These accounts of Iris Murdoch provide us with an opportunity to examine representations of what it means to live with dementia for someone who was known for her intellect.

We studied obituaries, news reports and photographs of Iris Murdoch which were published in the broadsheets the day following her death and were available to us in Scotland. All are concerned with telling the story of her life. We have listed them in Table I, distinguishing obituaries from reports (for which we show the titles) and assigning numbers for ease of referencing in our analysis. The objective of the analysis was to identify the stories that were told about 
Iris's life with and without dementia - accounts of a successful life that was dramatically transformed into the career of a person with dementia.

\section{The career of a person with dementia}

The term 'career' was adopted by Goffman 'to refer to any social strand of any person's course through life' (I $972: 527$ ). In applying the term to the category of 'mental patient', he was particularly concerned with 'the moral aspects of career - that is, the regular sequence of changes that career entails in the person's self and in his framework of imagery for judging himself and others' (I972: 528). The notion of a 'moral career' can be extended to the situation of a person with dementia, particularly when analysing the concluding accounts of a writer who is known for her moral concerns.

All the accounts discuss at some length Iris Murdoch's career and academic achievements. The Telegraph and Times obituaries do this notably, almost to the exclusion of any other narrative. Her Alzheimer's disease is often minimised. Bytheway and Johnson ( I996) say that midlife achievements are the main focus for obituaries and also that it is not uncommon for a diagnosis to be the only reference to the ill-health of the person. There is though, even within these accounts of her public life, evidence that something was happening to Iris Murdoch, evidence that may be familiar to others who have witnessed the early stages of Alzheimer's disease. The Independent and Telegraph both refer to what was thought to be her writer's block. Other comments also suggest early symptoms of dementia:

In later life the novels got longer and perhaps woollier. (7)

It is undeniable that things started to go wrong from the late Seventies onwards. The Sea, The Sea, which won the Booker Prize, is very far from being her best book, and after that a slow process of withdrawal began to take place. (5)

These judgements of her novels may have been made with the 'benefit' of hindsight: constructing a version of the past with the retrospective knowledge that she had dementia. Many of the narratives are also filled with more explicit terms and signs of affliction, such as experiencing a 'descent into Alzheimer's disease' (6). The career of the person with dementia is clearly seen by some to undergo a sudden and dramatic change:

The dread knock of Professor Alzheimer. (I I)

Iris Murdoch was struck down by Alzheimer's disease. (7) 
There is one commendable exception to this:

her memory started seriously to let her down with the onset of Alzheimer's disease. ( I)

This indicates that her Alzheimer's disease is not her total character, that she was with dementia rather than that had she become demented. But many of the ways in which Iris Murdoch is discussed in terms of her 'career', do refer to her being demented and do so in terms of signs of affliction:

an old age clouded by Alzheimer's disease. (3)

she was in a dreadful trance-like state. (3)

By the end of her life, stricken with Alzheimer's disease, she had no recollection or understanding. ( 13 )

There is a sense in which, because of her intellect, Alzheimer's disease was even more of a tragedy for Iris Murdoch than for others - the irony of someone who had engaged in the mental mapping of philosophy seen as the loss of mind. The photograph in the Guardian (3), for example, shows her with hands on head. Without contextual signposting, this could be interpreted as either grappling with philosophy or losing her mind: two very different junctures in the career she takes. The tragedy for Iris is pointedly summarised in the tributes:

An illness of the brain afflicting one who lived by her mind seems a particularly painful irony. (I3)

She was a marvellously clever woman, so her illness seemed doubly terrible. (3)

Alzheimer's disease took an increasingly tenacious grip upon her once fine mind. (I2)

\section{Conventional characterisations of good and bad}

Apart from her having been diagnosed with Alzheimer's disease, there are three things that people may have known about Iris Murdoch: that she was an author, that she was Irish and that she was a woman. Each of these becomes subject to conventional characterisations. We have already seen that her character as an author is described in terms of the life of the mind which is seen as ending with dementia. Much of her writing was concerned with 'a metaphysical battle between evil and good' (I2), and she is quoted as saying that her fiction was a 'hall of reflection' ( I 2). Within these obituaries, these themes are also reflected as good and bad. For instance, reference to her being Irish is subject to 
stereotypical characterisation. She was born in Dublin and moved to England as a child. Although her achievements are deemed to be English, some of her afflictions are seen to be Irish. She was said to 'inherit a more uncertain version of her mother's "shebeen soprano", ( I - a shebeen being an unlicensed house selling alcohol, and her mother being Irish. Her alcohol consumption is also referred to, with derogatory connotations associated with her Irish background rather than her academic life at Oxford:

In the early stages one thought she was just a bit muddly - like many of her compatriots in what she called 'that terrible Island', she could knock back prodigious quantities of alcohol. But of course, the memory lapses, and the pauses in speech turned out to be the early symptoms of the disease. (I I)

Also in the narratives, there is a prevailing image of purity, innocence and goodness. Although this may be characteristic of many obituaries, there is a sense of surprise which adds authenticity to their utterance. This surprise is that a woman of such remarkable intellect and success as a philosopher and writer, should possess what could be seen as a feminine and thoroughly 'good' side:

her friends spoke of her kindness and warmth and understanding... her concern with goodness. (9)

she was the kindest of Dutch uncles ... she sympathised. Totally. (I I)

she was no believer in God, but wrote: 'I have wanted to move from 'God' to 'Good'. (I3)

Iris looked like a Reverend Mother in mufti, and she was an endlessly kind, good woman. (I I)

It would be difficult to assess how much of this goodness has been applied retrospectively and how much could be attributed to her having Alzheimer's disease. Images of people with dementia draw on the stereotype of the 'holy innocent' that is also found in representations of people with learning disabilities (Eayrs et al. I995). There is a photograph in the Guardian, of Iris in old age accompanied by the caption 'Dame Iris Murdoch... she connected goodness against the temper of the times'. It is a serene image, reinforcing this core of goodness depicted in the narrative. It is ironic that any narrative was, presumably at this stage, lost to Iris Murdoch, yet her photographic image is still able to portray pure goodness. The tragedy of decline and loss of language sums up the dominant fears of our culture, but is not to be observed in this serene image of Iris: in a sense this image negates the fear. 


\section{The woman novelist in the family picture ${ }^{3}$}

Serenity and calmness can also be found in what the reports take from John Bayley's account:

our marriage is now getting somewhere. It is giving us no choice: and I am glad of that. Every day we are physically closer. (Io)

There is with this an implication that only with Alzheimer's disease, does Iris Murdoch slip into a gendered role within the marriage; one where she is dependent upon her husband and, through this dependency, one where he feels they are closer.

Of related significance are references to their being childless. Bytheway and Johnson ( I 996) found that of 86 obituaries examined, only 26 'report briefly the details of who had survived the deceased' (1996: 229). Thus, if it is unusual to make more than a mention to existing survivors, reference to lack of children may be a gender-specific comment, and one aimed at accounting for Iris Murdoch's professional success:

They did not have any children, claiming to have left the matter to fate. Iris Murdoch insisted, however, that her happy marriage was one of the most important things in her life. (9)

The fact that she was childless gave her vast reserves of emotional energy. ( I I)

These comments suggest that a woman has difficulty in achieving success in both career and family life. Children may, in their absence, be proposed as the qualification of Iris Murdoch's success, just as, in the image of women novelists analysed by Barthes (1973), the presence of children may act as the compensation for being a woman writer. In each case a price has to be paid. Even the childless Iris Murdoch can be incorporated into a gendered narrative through marriage and the expectations of family care.

\section{The caring narrative}

Gender representations play an important role in the discussions relating to John Bayley. In these accounts there are five photographs of Iris Murdoch in old age in which, significantly, she is accompanied by him, her husband. They produce a strong image and accompanying journalistic comment, and it is open to question whether this would have occurred if the gender roles had been reversed. Narrative of her husband also appears in her obituaries, and he is referred to as having 'enormous courage and self-sacrifice' (6). If it had been Iris Murdoch caring for her husband, this would probably have justified only cursory mention as it is expected that women will take the role of carer 
(Qureshi and Walker i989). Within the tributes to Iris Murdoch are numerous ones to her husband:

John nursed and cared for her with a good humour and courage which was the admiration of all their friends. ( I I)

John Bayley cared for her with devotion and tenderness throughout her final years. (I 2)

In her declining years, the example of her husband in looking after her earned gratitude and admiration. (4)

Further, Wilson attributes much of her work to John Bayley:

It is him we have to thank, not only for the novels, but also for the philosophy of the later years. (I I)

So it seems that the figure of virtue in Iris Murdoch is reflected onto John Bayley and that, in addition, he becomes her mind as she is seen to lose it. Not only is he seen as an heroic model of caring support to the afflicted Iris Murdoch, but also as continuing her intellectual work in later years. Whilst these tributes to the spouse of the deceased may be unusual by their inclusion in obituaries, through them, we do witness a close, trusting and respectful relationship. It was undoubtedly a changed and changing one which, through his empathetic treatment, would be consistent with maintaining Iris's 'personhood' (Kitwood I 997) rather than stressing any loss of self. This is further seen in his two books on Iris (Bayley i 998, i 999). An extract from the first of these is quoted in three of the newspapers we examined, and it reflects how close this relationship was. It also shows Bayley's view of the experience of dementia for Iris:

She is not sailing into the dark: the voyage is over, and under the dark escort of Alzheimer's she has arrived somewhere. So have I. $\left(6, \mathrm{I} 0, \mathrm{I}_{3}\right)$

\section{Conclusion}

We too, through an analysis of these narratives, have journeyed with Iris. Accounts upon death present a sequence of events, making metaphorical references that suggest a voyage or flow checked by struggles, a life course that is followed to its destination. Conventional biographical narratives are thereby presented with an ending. Authority to write concluding narratives is bestowed upon experts, often anonymous ones, with the implication of objectivity and detachment. In this way the self can be legitimately characterised by the expert other.

An author's obituaries involve telling the story of a storyteller. 
Aspects of their style of writing may become part of and be echoed in the tributes. For Iris Murdoch, the moral narrative relating to good and evil is a key theme that she examined in her work and which is now projected by others onto her. In this projection the author herself is silent. This silence is a poignant feature of all obituaries, in that the dead cannot tell their own story, but it is particularly poignant when someone with dementia has had their story and their self defined by others. Similarly, only recently has the biomedical, deterministic view of dementia been challenged in a way that may help break the silence and allow us to hear the voice of the person with dementia (Downs I 997). Where told by others, the story of dementia is presented as one of tragic loss, the embarkation on a fatal journey, the assumption of a doomed career.

Many of the descriptions of Iris Murdoch's career with dementia may have been applied retrospectively to depict a sudden and dramatic break. The obituaries present us with a chronological date of death, yet the accounts suggest a social death that may have occurred before this. This disjuncture is dementia, which is perceived to bring about a transformation of identity, separating the times with and without the disease. Knowing that someone has dementia may change the way that we interpret their biography, prompting further retrospective comments which attribute failings to the disease. Some of the accounts portray the dementia in essentialist terms, suggesting that Iris was demented rather than that she had dementia. Thus the disease is either ignored, or seen as a defining characteristic of her later years, or seen to leave Iris Murdoch with a sense of pure goodness.

Images of good and bad in the analysed accounts associate her Irish background with dubious characteristics, while noting her progress to become a great English intellect. For one engaged in intellectual pursuits, experiencing Alzheimer's disease is presented as a double tragedy. Our inability to comprehend and cope with afflictions of the mind experienced in Alzheimer's disease and in other dementias, reflects and reinforces societal values held about the mind. As Post points out: 'Too great a value emphasis on rationality and memory ... wrongly excludes people with dementia from the sphere of human dignity and respect' (Post I995:2). What remains, when these aspects of the mind are understood to be lost, is the stereotype of the holy innocent. We are thus presented with the vision of Iris Murdoch as a thoroughly good and pure woman, an image that may again have been applied retrospectively. Gender-specific comments relating to marriage, childlessness and expectations of family care, are interwoven in the accounts, and the virtues of purity and goodness, along with a once 
great intellect, are projected onto Iris Murdoch's husband in his role as carer, minder and the continuation of her mind.

The story of Iris Murdoch may be one that she herself would not have wished to be told. It could be argued however that one very positive aspect of the media coverage of Iris Murdoch's Alzheimer's disease is that it may have increased awareness of the condition. Alzheimer's disease is seen by many as a stigmatising affliction, and is often treated with silence. Acknowledging the dementia of someone well known for their intellectual achievements may go some way to reducing this stigma for all people with dementia. Yet the newspapers suggest otherwise in the way they incorporate conventional characterisations of dementia in their accounts.

The concluding narratives of Iris Murdoch's life suggest not only a journey that has reached its end, but a life course that has been tragically diverted. These accounts thus draw upon conventional narratives of life at its conclusion, as well as standard sequences embodied in the assumed career of a person with dementia. What is commonly known of Iris Murdoch - her authorship, her Irish origins and her gender - is interpreted by drawing on the available repertoire of accounts of these characteristics, in order to tell a story of loss and care, a narrative that reflects and reproduces the fears and hopes of the wider culture.

\section{NOTES}

I Similarly Zimmermann emphasises the reflexivity of accounts in his study of how 'records achieve the authority of objective and impersonal accounts of persons' lives' (I 974: I 28).

2 Furthermore it is reported that Iris Murdoch 'had requested that there should be no funeral or memorial service to honour her life' (IO).

3 'Where then is man in this family picture? Nowhere and everywhere, like the sky, the horizon, an authority which at once determines and limits a condition' (Barthes I973: 51).

\section{References}

Barthes, R. I 973. Mythologies (trans. Lavers, A.). Paladin, St Albans.. Bayley, J. 1998. Iris: A Memoir of Iris Murdoch. Duckworth, London.

Bayley, J. I999. Iris and the Friends: a Tear of Memories. Duckworth, London.

Bond, J. I 992. The medicalization of dementia. Fournal of Aging Studies, 6, 397-403.

Bytheway, B. and Johnson, J. I996. Valuing lives? Obituaries and the life course. Mortality, I, 2, 2 I 9-34.

Cohen, D. and Eisdorfer, G. ig86. The Loss of Self: a Family Resource for the Care of Alzheimer's Disease and Related Disorders. W.W. Norton, London.

Davis, R. I989. My Fourney into Alzheimer's Disease. Tyndale, Wheaton, Illinois.

Doernberg, M. ig89. Stolen Mind: the Slow Disappearance of Ray Doernberg. Algonquin Books, Chapel Hill. 
Downs, M. i 997. The emergence of the person in dementia research. Ageing and Society, I 7, 597-6o7.

Eayrs, C. B., Ellis, N., Jones, R. S. P. and Miller, B. I995. Representations of learning disability in the literature of charity campaigns.. In Markova, I. and Farr, R. M. (eds), Representations of Health, Illness and Handicap. Chur, Harwood, 67-89.

Friel-McGowin, D. F. I 993. Living in the Labyrinth: a Personal Journey through the Maze of Alzheimer's. Elder, San Francisco.

Goffman, E. I972. The moral career of the mental patient. In Manis, J. G. and Meltzer, B. N. (eds), Symbolic Interaction. Allyn and Bacon, Boston, 527-54.

Grant, L. I 998. Remind Me Who I Am Again. Granta Books, London.

Harding, N. and Palfrey, C. I 997. The Social Construction of Dementia. Jessica Kingsley Publishers, London and Philadelphia.

Harré, R. i 998. The Singular Self. Sage, London.

Holstein, M. I 998. Ethics and Alzheimer's disease: widening the lens. Fournal of Clinical Ethics, I, I 3-22.

Kermode, F. i 973. Literature, fiction and reality. In Burns, E. and Burns, T. (eds), Sociology of Literature and Drama. Penguin, Harmondsworth, 2 I $4^{-25}$.

Kitwood, T. I993. Towards a theory of dementia care: the interpersonal process. Ageing and Society, 13, 5 I-67.

Kitwood, T. 1997. Dementia Reconsidered: the Person Comes First. Open University Press, Buckingham.

Lyman, K. I989. Bringing the social back in: a critique of the biomedicalization of dementia. The Gerontologist, 29, 597-605.

Lyman, K. I998. Living with Alzheimer's disease: the creation of meaning among persons with dementia. The Fournal of Clinical Ethics, 9, 49-57.

Lyotard, J. I984. The Postmodern Condition: a Report on Knowledge (trans. Bennington, G. and Massumi, B.). University of Minnesota Press, Minneapolis.

Post, S. I 995. The Moral Challenge of Alzheimer Disease. Johns Hopkins University Press, Baltimore, MD.

Post, S. i 998. The fear of forgetfulness: a grassroots approach to an ethics of Alzheimer's disease. The Journal of Clinical Ethics, 9, 7 I-80.

Qureshi, H. and Walker, A. I989. The Caring Relationship: Elderly People and their Families. Macmillan, London and Basingstoke.

Ricoeur, P. I992. Oneself as Another (trans. Blamey, K.). Chicago University Press, Chicago.

Rose, L. I996. Show Me the Way to Go Home. Elder Books, San Francisco, California.

Strauss, A. I997. Mirrors and Masks: the Search for Identity. Transaction, New Brunswick, NJ.

Sweeting, H. and Gilhooly, M. r997. Dementia and the phenomenon of social death. Sociology of Health and Illness, r9, I, 93-I I 7.

Valentine, J. i998. Naming the other: power, politeness and the inflation of euphemisms. Sociological Research Online, 3, 4, < http:www.socresonline.org.uk/ socresonline $/ 3 / 4 / 7 \cdot \mathrm{html}>$.

Zimmermann, D. H. i974. Fact as practical accomplishment. In Turner, R. (ed), Ethnomethodology. Penguin, Harmondsworth, i 28-43.

Accepted I7 September 1999

Address for correspondence:

Gillian McColgan, Centre for Social Research on Dementia, Department of Applied Social Science, University of Stirling, Stirling, UK, FK 94 LA 